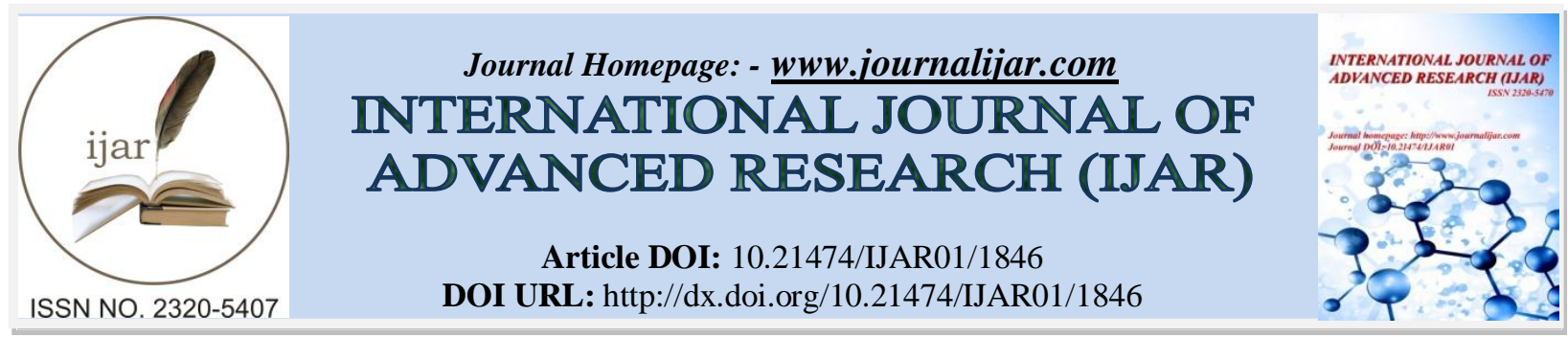

RESEARCH ARTICLE

\title{
EFFECT OF MAINTAINING TEMPERATURE ON DEVELOPMENT OF FOUNDRY SAND BASED GEOPOLYMER CONCRETE.
}

Sachin $^{1}$ and Er. Jatin Goyal ${ }^{2}$.

1. M.Tech Scholar, JCDM College of Engineering, Sirsa, Haryana.

2. Guide \& Assistant Professor, JCDM College of Engineering, Sirsa, Haryana.

\section{Manuscript Info}

Manuscript History

Received: 13 August 2016

Final Accepted: 22 September 2016

Published: October 2016

Key words:-

fly ash, foundry sand, alkaline solution, compressive strength

\section{Abstract}

Concrete is most commonly used in construction. The OPC releases $\mathrm{CO} 2$, consumes natural resources like shale, sandstone and limestone, require more energy during production. The $\mathrm{CO}_{2}$ produced one ton for every ton of OPC produced due to the calcination of limestone and combustion of fossil fuel. Cement is totally replaced by pozzolanic material that is rich in silica and alumina and activated by alkaline liquid to act as binder in concrete by means of polymer chains. These alkaline liquids are $\mathrm{NaOH}, \mathrm{Na} 2 \mathrm{Sio3}$. The foundry sand is also a waste byproduct of metal foundries. We have partially replaced the sand with foundry sand. The compressive strength is carried out by Compressive Testing Machine at 7 and 28 days. This paper shows the effect of maintaining various temperatures on geo-polymer concrete by utilizing waste by products.

Copy Right, IJAR, 2016,. All rights reserved.

\section{Introduction:-}

Concrete is a major construction material, has been used all around the world .The main constituent of concrete is cement. The cement is of two types PPC and OPC. The cement taken under study is OPC. OPC production is an extremely energy-intensive task, which produces high amount of carbon dioxide. So the environmental issue associated with OPC concrete. The geo-polymer technology was first introduced in 1978 by Davidovit . The fly ash is used instead of cement to produce geo-polymer concrete. Fly ash and alkaline solution is used to make binder which binds the coarse \& fine aggregate. It's a new technology that reduces carbon dioxide emission to the atmosphere.

Geo-polymer concrete is designed same as cement-concrete design methods. The gap between the coarse aggregate are filled with fine aggregates and gap of fine aggregate are filled with the binder material. Fine aggregates are those particles which are less than $4.75 \mathrm{~mm}$ e.g. crushed stone and natural sand. The foundry sand can be used as an alternate to river sand and it is available free of cost as a byproduct of metal foundries. Foundry sand is a waste material not easily disposed \& it requires more land to dispose it. So we can reuse foundry sand to make environment friendly concrete. 


\section{Material Used:-}

The following materials have been used in the experimental study:-

a. Fly ash: In this experimental work, Class F Low calcium fly ash (ASTM Class F) conforming to IS: 3812-1987 specifications, collected from Guru Nanak Dev Thermal Power Station, India is utilized in this study.

b. Fine aggregate: Zone -III locally available sand is used to confirm to IS:383-1970 having specific gravity 2.63 and fineness modulus of 3.32 .

c.Foundry sand: foundry sand was used as a partial replacement of natural sand, 10\%, 20\%, and 30\% having specific gravity 2.65 and fineness modulus 2.45. The foundry sand was obtained from DCM (Delhi Cloth Mills) Engineering Limited Ropar.

d. Coarse aggregate: locally available angular $20 \mathrm{~mm}$ graded aggregates are used to confirm to IS:383-1970 having specific gravity 2.72 .

e. Water: distilled water is used.

f. Alkaline solution: In this research Analytical Grade Sodium Hydroxide pellets and sodium silicate solution were used with $98 \%$ purity. The alkaline liquid is prepared by mixing both the solutions together. 1st of all sodium hydroxide pellets dissolved in distilled water. Sodium hydroxide and sodium silicate mixed together. The mass of $\mathrm{NaOH}$ solids in a solution varied depending on the concentration.

g. Concentration of Sodium Hydroxide: The mass of $\mathrm{NaOH}$ solids in a solution varied depending on the concentration of the solution expressed in terms of molar. The molarity of $\mathrm{NaOH}$ solution with a concentration of $8 \mathrm{M}$ consisted of $8 \times 40=320$ grams of $\mathrm{NaOH}$ solid pellet per litre of the solution, where 40 is the molecular weight of $\mathrm{NaOH}$, similar as for other morality. Increasing molar concentration increase in the strength.

h. Maintaining: On the previous studies geo-polymer concrete did not attain strength at room temperature or by water curing. The concrete harden in maintaining or hot maintaining and the minimum maintaining period should be 24 hours.

\section{Mixing, Casting and Maintaining:-}

Mixing:- The aggregates were used in SSD [Saturated Surface Dry] condition. Mixed the aggregates and fly ash together in dry state for 3 minutes in mixer after that alkaline solution was added in dry material and mix for another minutes. The alkaline solution prepared $24 \mathrm{hrs}$ prior to use.

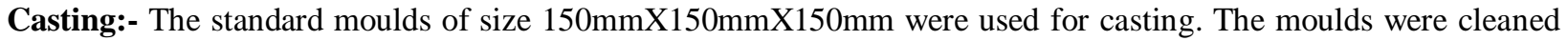
and oil was applied on all sides of moulds before casting. The concrete was poured in three layers in mould. The table vibrator was used for compaction.

Maintaining:- After casting the specimens were placed in oven for $24 \mathrm{hrs}$. The concrete was de-moulded and then placed at room temperature. For ambient maintaining specimen were placed in room temperature after casting.

Testing:- After mixing, casting and maintaining the specimens were tested. The cubes of size $150 \times 150 \times 150 \mathrm{~mm}$ were casted and tested. These cubes were tested by CTM machine. The test samples were placed in the compression testing machine and load was applied to the cross section of specimen gradually until the cube failed. The load at the failure divided by area of cube gives the compressive strength.

\section{Experimental Work:-}

In this research the total no. of 72 specimens was cast and tested, 36 for 7 days and 36 for 28 days. In this concrete we use fly ash instead of cement along with alkaline solution, coarse aggregate, and fine aggregate. Maintaining is done at ambient maintaining, $60^{\circ} \mathrm{C}$ and $90^{\circ} \mathrm{C}$. In this research black foundry sand or waste foundry sand was used, the foundry sand is replaced with normal sand to $10 \%, 20 \%$ and $30 \%$. The engineering properties of aggregates and concrete were tested according to the Indian Standards. For testing of compressive strength of concrete, $150 \mathrm{mmX} 150 \mathrm{mmX} 150 \mathrm{~mm}$ cubes were casted and tested. The compressive strength of concrete was measured at 7 days and 28 days.

\section{Design Mix:-}

Assume density of aggregate as unit weight of concrete $=2400 \mathrm{~kg} / \mathrm{m}^{3}$.

Mass of Combined aggregate $=75-80 \%$

Let we take $76.30 \%$ aggregate

$2400 \times 0.76 .30 \%=1824 \mathrm{~kg} / \mathrm{m}^{3}$ 
Mass of combined aggregate $=1824 \mathrm{~kg} / \mathrm{m}^{3}$

Mass of coarse aggregate $=1221 \mathrm{~kg} / \mathrm{m}^{3}$ and mass of fine aggregate $=610.5 \mathrm{~kg} / \mathrm{m}^{3}$

(As ratio of fine aggregate to total aggregate $=.35$ )

Mass of Fly ash and alkaline Liquid $=2400-1831.5=568.5 \mathrm{~kg} / \mathrm{m}^{3}$

Let us take alkaline liquid to fly ash ratio as 0.4 .

Now the mass of fly ash $=(552) /(1.4)=407 \mathrm{~kg} / \mathrm{m}^{3}$

Mass of alkaline liquid $=568.5-407=161.5 \mathrm{~kg} / \mathrm{m}^{3}$

Let us consider the ratio of $\mathrm{NaOH}$ to $\mathrm{Na}_{2} \mathrm{SiO}_{3}$ as 2.5.

Now mass of $\mathrm{NaOH}$ solution $=(161.5) /(3.5)=46.14 \mathrm{~kg} / \mathrm{m}^{3}$

Mass of $\mathrm{Na}_{2} \mathrm{SiO}_{3}$ solution $=161.5-46.14=115.40 \mathrm{~kg} / \mathrm{m}^{3}$

\section{Result Table:-}

Mixture proportion:-

\begin{tabular}{|c|c|c|c|c|c|}
\hline \multicolumn{6}{|c|}{ Fly ash based geo-polymer concrete for M 20} \\
\hline Sr. No. & Material & $\begin{array}{l}\text { o\% } \\
\text { replacement of } \\
\text { foundry } \\
\text { Sand }\left(\mathrm{kg} / \mathrm{m}^{3}\right)\end{array}$ & $\begin{array}{l}\quad 10 \% \\
\text { replacement of } \\
\text { foundry } \\
\text { Sand }\left(\mathrm{kg} / \mathrm{m}^{3}\right)\end{array}$ & \begin{tabular}{l}
\multicolumn{1}{c}{$20 \%$} \\
replacement of \\
foundry \\
Sand $\left(\mathrm{kg} / \mathrm{m}^{3}\right)$
\end{tabular} & $\begin{array}{l}30 \% \text { replacement } \\
\text { of } \\
\operatorname{sand}\left(\mathrm{kg} / \mathrm{m}^{3}\right)\end{array}$ \\
\hline 1 & Fly ash & 407 & 407 & 407 & 407 \\
\hline 2 & Normal Sand & 610.5 & 549.45 & 488.4 & 427.35 \\
\hline 3 & Foundry sand & 000 & 61.05 & 122.1 & 183.15 \\
\hline 5 & Coarse aggregate & 1221 & 1221 & 1221 & 1221 \\
\hline 6 & $\mathrm{NaOH}$ & 46.14 & 46.14 & 46.14 & 46.14 \\
\hline 7 & $\mathrm{Na}_{2} \mathrm{SiO}_{3}$ & 115.4 & 115.4 & 115.4 & 115.4 \\
\hline 8 & Total & 2400 & 2400 & 2400 & 2400 \\
\hline 9 & Molarity & 16 & 16 & 16 & 16 \\
\hline 10 & $\begin{array}{l}\text { Ratio of mix. } \\
\text { Prop. }\end{array}$ & $1: 1.5: 3$ & $1: 1.5: 3$ & $1: 1.5: 3$ & $1: 1.5: 3$ \\
\hline 11 & $\begin{array}{l}\text { Liquid/binder } \\
\text { Ratio }\end{array}$ & 0.40 & 0.40 & 0.40 & 0.40 \\
\hline
\end{tabular}

Compressive strength of M20 geo-polymer concrete at 7 days.

\begin{tabular}{|c|c|c|c|c|c|c|c|c|}
\hline \multirow{2}{*}{$\begin{array}{l}\text { Maintaining } \\
\text { Temp. }\end{array}$} & \multicolumn{2}{|l|}{$0 \%$} & \multicolumn{2}{|c|}{$10 \%$ replacement } & \multicolumn{2}{|c|}{$20 \%$ replacement } & \multicolumn{2}{|c|}{$30 \%$ replacement } \\
\hline & $\begin{array}{l}\text { Comp. } \\
\text { strength }\end{array}$ & $\begin{array}{l}\text { Density } \\
\mathrm{Kg} / \mathrm{m}^{3}\end{array}$ & $\begin{array}{l}\text { Comp. } \\
\text { strength }\end{array}$ & $\begin{array}{l}\text { Density } \\
\mathrm{Kg} / \mathrm{m}^{3}\end{array}$ & $\begin{array}{l}\text { Comp. } \\
\text { strength }\end{array}$ & $\begin{array}{l}\text { Density } \\
\mathrm{Kg} / \mathrm{m}^{3}\end{array}$ & $\begin{array}{l}\text { Comp. } \\
\text { strength }\end{array}$ & $\begin{array}{l}\text { Density } \\
\mathrm{Kg} / \mathrm{m}^{3}\end{array}$ \\
\hline Ambient & 14 & 2248 & 13 & 2300 & 12.5 & 2384 & 12.5 & 2346 \\
\hline $60^{\circ} \mathrm{C}$ & 16 & 2356 & 17 & 2296 & 16 & 2374 & 15 & 2338 \\
\hline $90^{\circ} \mathrm{C}$ & 18 & 2366 & 18.5 & 2315 & 17.5 & 2396 & 16 & 2446 \\
\hline
\end{tabular}

Compressive strength of $\mathrm{M20}$ geo-polymer concrete at 28 days.

\begin{tabular}{|c|c|c|c|c|c|c|c|c|}
\hline \multirow{2}{*}{$\begin{array}{l}\text { Maintaining } \\
\text { Temp. }\end{array}$} & \multicolumn{2}{|c|}{ No replacement } & \multicolumn{2}{|c|}{$10 \%$ replacement } & \multicolumn{2}{|c|}{$20 \%$ replacement } & \multicolumn{2}{|c|}{$30 \%$ replacement } \\
\hline & $\begin{array}{l}\text { Comp. } \\
\text { strength }\end{array}$ & $\begin{array}{l}\text { Density } \\
\mathrm{Kg} / \mathrm{m}^{3}\end{array}$ & $\begin{array}{l}\text { Comp. } \\
\text { strength }\end{array}$ & $\begin{array}{l}\text { Density } \\
\mathrm{Kg} / \mathrm{m}^{3}\end{array}$ & $\begin{array}{l}\text { Comp. } \\
\text { strength }\end{array}$ & $\begin{array}{l}\text { Density } \\
\mathrm{Kg} / \mathrm{m}^{3}\end{array}$ & $\begin{array}{l}\text { Comp. } \\
\text { strength }\end{array}$ & $\begin{array}{l}\text { Density } \\
\mathrm{Kg} / \mathrm{m}^{3}\end{array}$ \\
\hline Ambient & 20 & 2265 & 19 & 2245 & 18 & 2308 & 18 & 2366 \\
\hline $60^{\circ} \mathrm{C}$ & 24 & 2173 & 25 & 2213 & 24 & 2327 & 24 & 2346 \\
\hline $90^{\circ} \mathrm{C}$ & 25 & 2252 & 26 & 2114 & 23 & 2370 & 22 & 2429 \\
\hline
\end{tabular}




\section{Placing the figures:-}

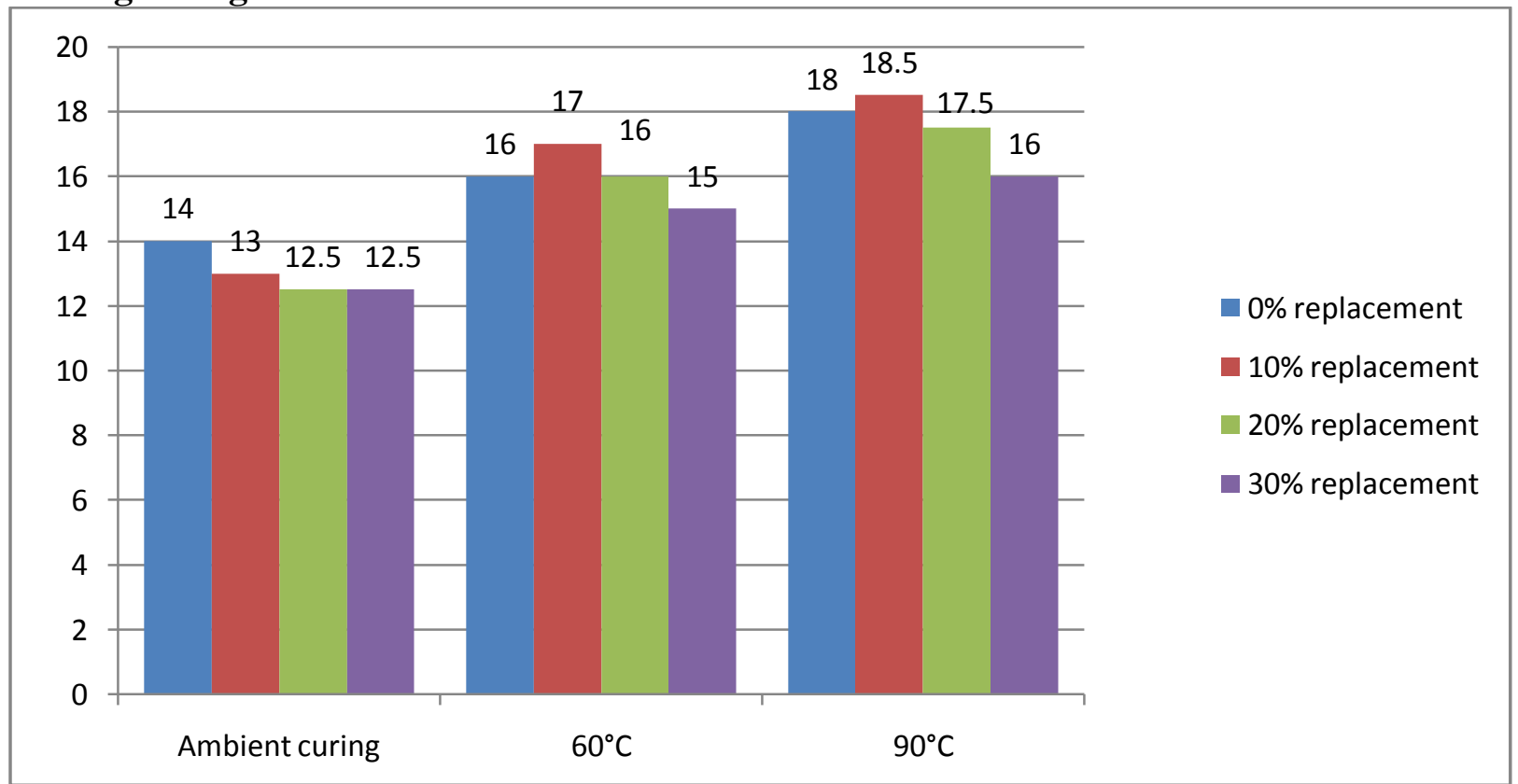

Figure 1:- Compressive strength of GPC w.r.t. different maintaining condition and replacement of foundry sand at 7 days.

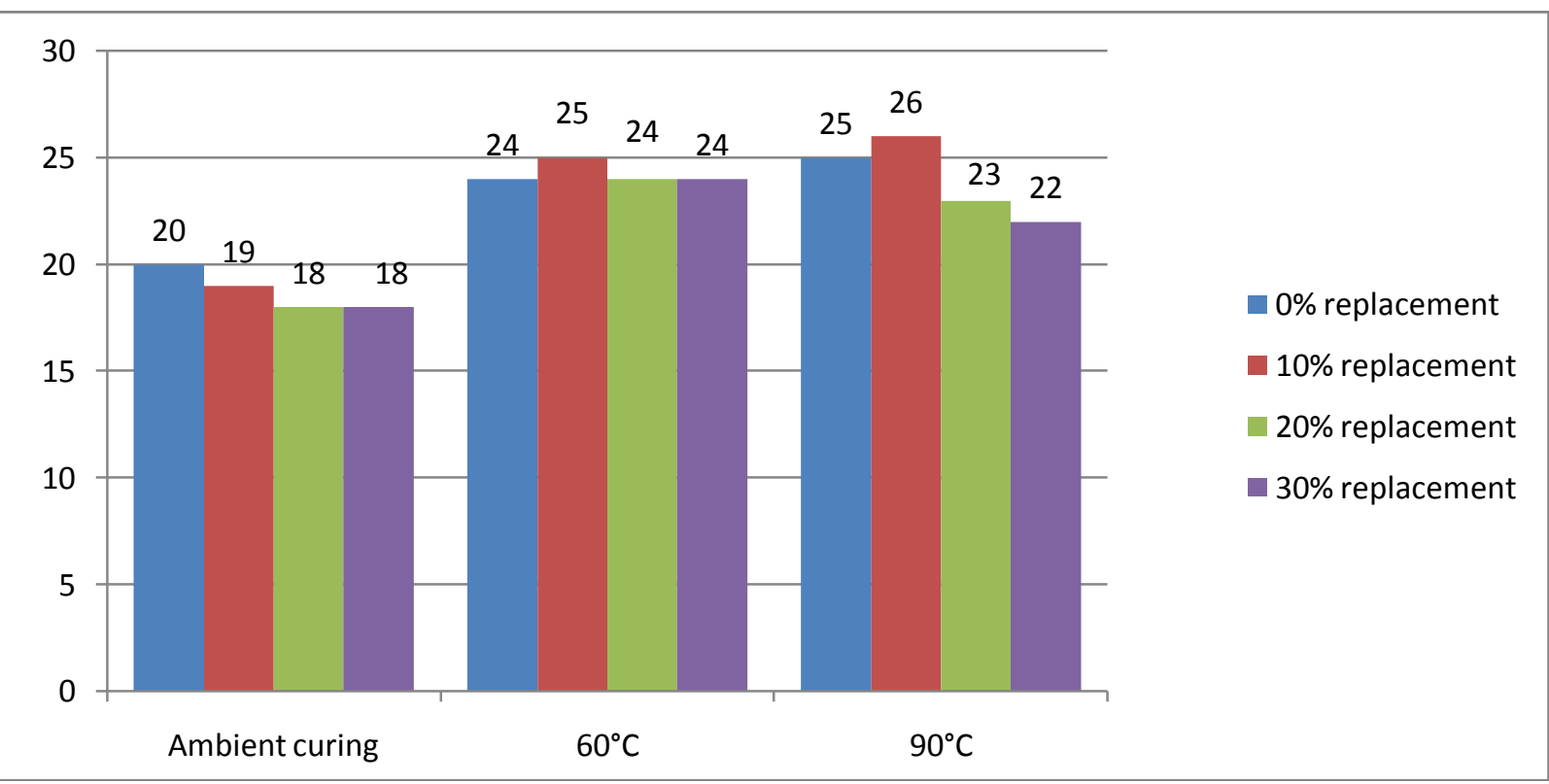

Figure 2:- Compressive strength of GPC w.r.t. different maintaining condition and replacement of foundry sand at

\section{Discussion:-}

28 days.

It has been clearly shown by the above mentioned results that the Compressive strength of M20 geo-polymer concrete at 7 day is maximum at $10 \%$ replacement with foundry sand at $90^{\circ} \mathrm{C}$ which is $18.5 \mathrm{Kg} / \mathrm{m}^{3}$ and the compressive strength of 7 days is minimum at $10 \%$ replacement with foundry sand at ambient temperature which is $13 \mathrm{~kg} / \mathrm{m}^{3}$. The Compressive strength of M20 geo-polymer concrete at 28 day is maximum at $10 \%$ replacement with foundry sand at $90^{\circ} \mathrm{C}$ which is $26 \mathrm{Kg} / \mathrm{m}^{3}$ and the compressive strength of 28 days is minimum at $30 \%$ replacement with foundry sand at ambient temperature which is $18 \mathrm{~kg} / \mathrm{m}^{3}$. 


\section{Conclusion:-}

It can be concluded from this study that by maintaining temperature the different affects occur on the strength of geo-polymer concrete.

- The geo-polymer concrete gives $80 \%$ strength at 7 days maintaining.

- In fly ash based concrete using foundry sand, the strength increased with increase in temperature up to a certain temperature.

- The compressive strength of fly ash based GPC concrete not gives good results in ambient maintaining. So heat maintaining is the better option than the ambient maintaining.

- The compressive strength of GPC using fly ash was found to be increasing with replacement of foundry sand. It was found that $10 \%$ replacement of foundry sand by normal sand gives more strength as compare to without replacement. Geo-polymer concrete holds great promise as on eco-friendly.

Hence it could be summarized that the fly ash based concrete geo-polymer concrete with partial replacement of foundry sand by normal sand could be effectively used in geo-polymer concrete.

\section{Recommendation:-}

1. The compressive strength of geo-polymer concrete using foundry sand is more than OPC, so we can use GPC in construction.

2. The making of GPC can reduce carbon dioxide from atmosphere, so GPC is more eco-friendly than OPC.

3. The manufacturing cost of GPC is more economical then OPC.

\section{References:-}

1. Joseph Davidovits, Geopolymer Institute 02100 Saint-Quentin, France, "Environmentally Driven Geopolymer Cement Applications", Geopolymer 2002 Conference, Melbourne, Australia, October 2002.

2. DjwantoroHardjito, Steenie E. Wallah, Dody M. J. Sumajouw, and B.VijayaRangan, "Development of Fly AshBased Geopolymer Concrete", ACI materials journal, November-December 2004.

3. DjwantoroHardjito, Steenie E. Wallah, Dody M.J. Sumajouw, and B.V. Rangan, "Factors Influencing The Compressive Strength Of Fly Ash-Based Geopolymer Concrete", civil engineering dimension, Vol. 6, issue No. 2, 2004.

4. D Hardjito, S E Wallah, D M J Sumajouw, B.V. Rangan, "Introducing Fly Ash-Based Geopolymer Concrete (Manufacture And Engineering Properties)",30th conference on our world in concrete \& structures, 24 August 2005.

5. Steenie Edward Wallah, "Drying Shrinkage of Heat-Cured Fly Ash Based Geopolymer Concrete", Modern Applied Science www.ccsenet.org/journal.html, vol-3, issue-12, December 2009.

6. N A Lloyd and B V Rangan, "Geopolymer Concrete with Fly Ash, second international conference on sustainable construction material and technologies", June 2010.

7. Raijiwala D.B., PatH H.S., "Geopolymer Concrete (A Green Concrete)", 2nd International Conference on Chemical, Biological and Environmental Engineering, 2010.

8. K.A Anuar, Ridzuan A.R.M, Ismail S, "Strength Characteristics of Geopolymer Concrete Containing Recycled Concrete Aggregate", International Journal of Civil \& Environmental Engineering ,Vol-11 ,Issue-01,February 2011.

9. Mohd Mustafa Al Bakri, H. Mohammed, H. Kamarudin, I. KhairulNiza and Y. Zarina, "fly ash-based geopolymer concrete without Portland Cement", Journal of Engineering and Technology Research Vol. 3(1),January- 2011.

10. Dali Bondar, Faculty member of Ministry of Energy, Iran, "Geopolymer Concrete as a New Type of Sustainable Construction Materials", $3^{\text {rd }}$ International conference on sustainable material and technologies. 